\title{
Tutkijanaiset sukupuolistuneessa yliopisto-organisaatiossa
}

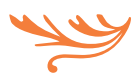

\author{
Suomessa valtaosa yliopisto-opiskelijoista on \\ naisia. Yliopistojen naisistuminen ei kuitenkaan \\ ole poistanut niiden tasa-arvo-ongelmia. \\ Yliopisto-organisaation sukupuolistavia käytäntöjä \\ pitävät yllä niin miehet kuin naiset.
}

$\mathbf{y}$

SUOMESSA NAISET OVAT OLLEET PITKÄÄN enemmistö yliopisto-opiskelijoista ja perustutkinnon suorittaneista. Samoin tieteellisen jatkotutkinnon suorittaneiden määrässä sukupuolijakauma on huomattavasti kaventunut vuosien saatossa. Esimerkiksi vuonna 1990 naisten osuus ylemmän jatkotutkinnon suorittaneista oli 32 prosenttia, kun taas vuonna 2014 naisväittelijöiden osuus oli kasvanut yli puoleen, 53 prosenttiin (KOTA-tietokanta, Vipunentietokanta).

Naisistumisen vuoksi suomalaista yliopistojärjestelmää on kuvattu jopa tutkijanaisten paratiisiksi, jossa sukupuolten tasa-arvo ja yhdenvertaisuus ovat toteutuneet. Julkisuudessa on väläytelty uhkakuvia naisvaarasta ja pelätty naisvyöryn muuttavan tutkija- miehen uhanalaiseksi lajiksi tulevaisuudessa. (Ks. esim. Raivio 2002.)

Kuitenkin useiden kansainvälisten ja kotimaisten tutkimusten perusteella sukupuoli on edelleen merkittävä tutkijoita eriarvostava tekijä (ks. esim. Bagilhole \& Goode 2001; Barone 2011; Blickenstaff; 2005; Brunila 2009; Harley, 2003; Husu 2001; Julkunen 2004; Kantola 2005; Naskali 2004; O’Connor 2000; Perna 2005; Van den Brink \& Benschop 2011; Wennerås \& Wold 1997). Tutkimukset osoittavat, että tutkijanaisten kohtaama sukupuolinen syrjintä ja epätasa-arvoinen kohtelu ovat pikemminkin sääntö kuin poikkeus yliopistomaailmassa. Tutkimukset tuovat esille, että yliopisto-organisaatiot ovat vahvasti segregoituneet niin horisontaalisesti kuin vertikaali- 
sesti. Opinnoissa ja tieteellisissä tutkimuksissa erottuvat edelleen miesten ja naisten alat. Esimerkiksi Suomessa teknillistieteellisellä koulutusalalla naisopiskelijoiden osuus oli vain 22 prosenttia vuonna 2014 (Vipunen-tietokanta).

Naiset ovat enemmistö yliopiston alemmilla hierarkiatasoilla ja miehet ovat enemmistönä professuureissa ja päättävissä asemissa. Naisten aliedustus tieteen hierarkiassa on useiden tutkimusten mukaan osoitettu olevan pysyvä ja universaali ilmiö, huolimatta korkeakoulutuksen historiallisesta vaihtelusta eri maissa tai erilaisista kansallisista ja kansainvälisistä tasa-arvotoimista. (Ks. esim. Foster 2001; Nikunen 2006; Seierstad \& Healy 2012.)

Tutkimukset ovat tuottaneet tärkeää tietoa tiedeyhteisön organisaatiokulttuurissa ja toimintaympäristössä esiintyvistä sukupuolistuneista käytänteistä ja piirteistä. Niitä ovat esimerkiksi tutkijanaisten tutkijamiehiä hitaampi urakehitys; sukupuolistunut rekrytointi-, valinta- ja ylenemispolitiikka; naisten "näkymättömyys"; sekä keskeisten roolimallien puute. Jopa tutkijanaisten ulossulkemista tiedeyhteisöstä sekä heidän tieteellisten kykyjensä aliarvioimista on havaittu. (Benschop \& Brouns 2003; Husu 2001; Katila \& Meriläinen 1999; 2002; Knights \& Richards 2003; Van den Brink \& Benschop 2012.)

Viime aikoina tutkimuksissa on kiinnitetty huomiota uuden yliopistojärjestelmän mukanaan tuomiin sukupuolivaikutuksiin. Tutkimustulokset kertovat, että yliopistokulttuurin muutos on entisestään heikentänyt tutkijanaisten asemaa. Ongelmia on koettu palkkojen, työmäärän ja -ajan, määräaikaisten työsuhteiden lisääntymisen, rahoituksen saamisen sekä perheen ja työn yhdistämisen osalta. Myös maskuliinisen yliopistokulttuurin on koettu vahvistuneen. (Esim. Acker \& Armenti 2004; Anderson 2006; Currie, Harris \& Thiele 2000.)

Huolimatta tutkimustuloksista ja syrjinnän kieltävistä laeista, tutkijanaisten asema ei ole parantunut akateemisessa maailmassa. Yhtenä merkittävänä syynä tähän voi pitää sitä, että yliopisto-organisaatiot näyttäytyvät pitkälti sukupuolineutraaleina. Yliopiston ymmärtäminen sukupuolineutraalina johtaa tavallisesti siihen, ettei tutkijanaisten kohtaamia sukupuolisen syrjinnän muotoja tunnisteta, saati tunnusteta. Sukupuolineutraalin ajattelutavan mukaisesti sukupuolella ei ole merkitystä, vaan ainoastaan yksilön henkilökohtaiset kyvyt ratkaisevat millaiseksi hänen asemansa yliopisto-organisaatiossa muodostuu. (Huhta, Lavikka, Leinonen, Rissanen, Uosukainen \& Ylöstalo 2005, 28; Nikunen 2006, 6.)

Lavikka on todennut, että organisaatioiden sukupuolineutraaliudessa on kysymys naamioituneesta hegemonisesta maskuliinisuudesta, jonka havaitsemisen ja johon reagoimisen sukupuolineutraali kulttuuri pyrkii vaimentamaan tai estämään. Näin sukupuolineutraaliudeksi identifioituva maskuliinisuus normina ja kulttuurina voi säilyttää hegemonisen jatkuvuutensa organisaatioissa yhteiskunnan tasa-arvonormeista ja laeista huolimatta. (Lavikka 2004, 43.) Sukupuolineutraaliuden ideaa pyritään vahvistamaan erilaisten selitysmallien avulla (Holli 2002, 13-14). Näitä ovat esimerkiksi yliopistomaailman naisistumiseen viittaavat puheenvuorot sekä suomalaisen yliopistojärjestelmän mieltäminen tasa-arvon edelläkävijänä.

Tämä artikkeli tuo esille sukupuolineutraliteettiajatteluun liittyviä ongelmia ja tarkastelee yliopistoorganisaatiota kauttaaltaan sukupuolistuneena. Päämääränä on tuoda näkyväksi yliopiston organisaatiokulttuurissa esiintyviä sukupuolistuneita prosesseja ja rakenteita, jotka heikentävät tutkijanaisten asemaa. Tavoitteena on osoittaa näiden sukupuolistuneiden prosessien pysyvyys ja hidas muuttuvuus. Artikkeli kyseenalaistaa yleisen käsityksen, jonka mukaan naisistumisen myötä yliopistomaailman tasa-arvoongelmat olisivat poistuneet tai korjaantumassa. Artikkelissa pohditaan myös yliopistokulttuurin muutoksen tuomia sukupuolivaikutuksia.

\section{TUTKIMUSAINEISTO JA -MENETELMÄT}

Artikkelissa käytetty tutkimusaineisto kerättiin tutkijanaisten asemaa yliopistossa käsittelevän pro gradu -tutkielman yhteydessä. Aineisto on kerätty sähköisellä Webropol-kyselylomakkeella keväällä 2012. Kyselylomake sisälsi monivalintaisia ja skaaloihin perustuvia kysymystyyppejä sekä avoimia vastausmahdollisuuksia. Tutkimusaineisto kerättiin yliopistossa, joka on yksi Suomen naisistuneimpia yliopistoja. Kohdeyliopistossa vuonna 2012 naisopiskelijoiden 
osuus oli 70,8 prosenttia. Tieteellistä jatkotutkimusta suorittavien naisten osuus oli 67 prosenttia. Lisäksi vuonna 2012 opetus- ja tutkimushenkilöstön osalta naisten määrä oli 59 prosenttia, joista naisprofessoreiden osuus oli 56 prosenttia. (Vipunen-tietokanta.)

Tutkimukseen osallistumispyyntö lähetettiin 142 tutkijanaiselle. Tutkijaksi määriteltiin naiset, jotka olivat suorittaneet tai olivat suorittamassa tieteellistä jatkotutkintoa (lisensiaatti/tohtori). Tutkimuksessa ei huomioitu yliopiston ulkopuolella työskenteleviä dosentteja.

Tutkimukseen vastasi 64 tutkijanaista ja vastausprosentiksi muodostui 45,1. Kyselyyn vastanneiden ikäjakauma oli melko tasainen. Suurimmat ikäryhmät olivat 34-43-vuotiaat ja 44-53-vuotiaat. Valtaosa vastaajista oli ammattinimikkeeltään joko tutkijoita, professoreita tai yliopistonlehtoreita ja he edustivat monia eri tieteenaloja. Vastauksia saatiin oikeus-, yhteiskunta-, taide- ja kasvatusalan tutkijanaisilta. Enemmistö vastaajista työskenteli kokoaikaisessa työsuhteessa. Heistä 56,3 prosenttia toimi määräaikaisessa työsuhteessa ja 43,8 prosentilla oli toistaiseksi voimassa oleva työsuhde.

Tutkimus oli lähestymistavaltaan monimetodinen eli siinä yhdistyivät laadullinen ja määrällinen tutkimusote. Tutkimuskirjallisuudessa laadullisen ja märällisen menetelmän yhteiskäyttöä on kuvattu triangulaation avulla. Monimetodinen lähestymistapa tarkoittaa, että tutkimuksessa yhdistetään erilaisia tutkimusmetodeja, erilaisia tutkimusaineistoja, lähestymistapoja tai tutkijoita. (Cohen, Lawrence \& Morrison 2000, 112.) Tutkimuksessa monimetodista tutkimustapaa käytettiin sekä aineistonkeruussa että aineiston analyysissa.

Tutkimuksen tavoitteena oli saada tietoa tutkijanaisten asemaa määrittävistä tekijöistä yliopiston organisaatiokulttuurissa. Tässä artikkelissa keskitytään ensisijaisesti kyselyn sukupuolista syrjintää käsittelevään osa-alueeseen, joka näytti vaikuttavan merkittävästi tutkijanaisten asemaan. Artikkelin pääpaino on tutkimuksen avoimissa vastauksissa, joita ei juurikaan analysoitu varsinaisen opinnäytteen yhteydessä. Kuitenkin avointen vastausten osuus kyselyssä oli merkittävä ja niihin oli vastattu huolellisesti. Tekstiosuuksien kautta saatua aineistoa kertyi yli 30 sivua.

Avoimia vastauksia analysoitiin teoriaohjaavan sisällönanalyysin avulla. Tällä tarkoitetaan aineiston analyysin muotoa, jossa tuodaan esille tutkijoiden kytkennät aikaisempiin teorioihin. Aineiston analyysin lähtökohtana toimivat olemassa olevat teoreettiset lähtökohdat ja käsitteet. Olennaista on kuitenkin, että aikaisempaa tietoa ei testata teoreettisesti, vaan sen avulla voidaan löytää uusia näkökulmia tutkittavasta aiheesta. (Tuomi \& Sarajärvi 2009, 118.) Aineiston analyysin työkaluna toimi yhdysvaltalaisen sosiologin Joan Ackerin (1990, 1992, 2006) kehittämä sukupuolistuneen organisaation teoria ja erityisesti siinä esiintyvät sukupuolistuneet prosessit.

Aineiston uudelleen analysointi noudatti kolmea vaihetta. Nämä olivat aineiston redusointi eli pelkistäminen, aineiston klusterisointi eli ryhmittely sekä abstrahointi eli teoreettisten käsitteiden muodostaminen (Tuomi \& Sarajärvi 2009, 108-111). Aloitimme aineiston pelkistämisen alleviivaamalla avoimista vastauksista sellaisia lauseita ja ajatuskokonaisuuksia, jotka olivat keskeisiä artikkelimme päätavoitteen kannalta. Kirjasimme ylös alleviivatut vastaukset ja tiivistimme ne helpommin ymmärrettävään muotoon.

Analyysin toisessa vaiheessa yhdistelimme pelkistettyjä ilmauksia, jotka liittyivät läheisesti yhteen esimerkiksi jonkin ominaisuuden perusteella. Samaa aihekokonaisuutta käsittelevät ilmaukset ryhmittelimme luokiksi ja nimesimme luokat niiden sisällön mukaan. Näin muodostimme erilaisia alaluokkia ja tarkempi kuva avoimien vastauksien sisällöstä alkoi muodostua. Jatkoimme alaluokkien ryhmittelyä ja muodostimme niistä varsinaisia tutkimusaihetta kuvaavia pääluokkia.

Viimeisessä analyysin vaiheessa ryhdyimme muodostamaan syntyneistä pääluokista teoreettisia käsitteitä. Pääluokat johdettiin neljään jo aikaisemmasta teoriasta tunnettuun sukupuolistuneeseen prosessiin, jotka olivat: sukupuolistuneet työnjaot, sukupuolistuneet mielikuvat, sukupuolistunut vuorovaikutus ja sukupuolistunut itsemäärittely. Tässä vaiheessa syntyi myös uusi aikaisemmasta teoriasta poikkeava pääluokka, jonka nimesimme yliopistokulttuurin muutokseksi.

Huomioitavaa oli tutkimusaiheen arkaluonteisuus, joka tuli esille tutkimuksen kuluessa. Kyselyn vastaamisaikana saimme useita yhteydenottoja, joissa tutkijanaiset halusivat varmistaa sen, etteivät he 
tule tunnistetuksi tutkimuksessa. Moni tutkijanaisista myönsi pelkäävänsä, että kyselyyn vastaaminen voisi haitata esimerkiksi heidän urallaan etenemistä tai he voisivat joutua vaikeuksiin tiedeyhteisössään.

Tutkimusetiikan perusteisiin kuuluu, että tutkittaville tulee heidän sitä halutessaan taata mahdollisuus säilyä anonyymeinä valmiissa tutkimuksessa. Lähtökohtana on tarve suojella tutkittavia niiltä mahdollisilta negatiivisilta vaikutuksilta, joita heidän tunnistamisensa saisi aikaan tutkimuksen julkaisun jälkeen. (Kuula 2006, 201; Mäkinen 2006, 114.) Koko tutkimusprosessimme ajan olemme suojelleet tutkimukseen osallistuneiden anonymiteettiä tarkoin. Valitsimme artikkelissamme käytettävät suorat aineistositaatit harkiten. Aineistositaatit eivät sisällä sellaisia tunnistetietoja, joista tutkimukseen osallistunut olisi mahdollista tunnistaa. Lisäksi katsoimme järkeväksi, ettemme käytä aineistoesimerkkien perässä vastaajien taustatietoja, kuten ikää, tiedekuntaa tai ammattinimikettä. Tunnistetietojen käyttö olisi voinut vaarantaa vastaajien anonymiteetin paljastumisen, koska tutkimuskohteemme on pienehkö yliopisto.

\section{TEOREETTINEN TAUSTA}

Artikkelin teoreettinen tausta pohjautuu Joan Ackerin $(1990,1992,2006)$ kehittämään sukupuolistuneen organisaation teoriaan. Teoriassa organisaation prosessit, rakenteet ja resurssit ymmärretään kauttaaltaan sukupuolistuneina. Teoria toimii analyyttisenä työkaluna, jonka avulla yliopisto-organisaatiota voidaan tarkastella sukupuolinäkökulmasta käsin.

Ackerin (mt.) mukaan sukupuolistuneet prosessit ovat käytänteitä, ajattelutapoja, mielikuvia ja asenteita, joiden avulla sukupuolet erotaan toisistaan. Sukupuolistuneisiin prosesseihin liittyy myös valta-aspekti, jonka avulla tuotetaan, uusinnetaan ja ylläpidetään hegemonista maskuliinisuutta. Acker erottaa organisaatioiden toiminnasta neljä erilaista sukupuolistunutta prosessia. Nämä prosessit ovat: sukupuolistuneet työnjaot, sukupuolistuneet symbolit ja mielikuvat, sukupuolistunut vuorovaikutus sekä sukupuolistunut itsemäärittely. (Acker 1992, 251.)

Sukupuolistuneet prosessit voivat esiintyä organisaatiossa avoimina, mutta hyvin usein ne ovat piilossa ja näkymättömiä. Nämä prosessit eivät ole irrallisia, vaan ne sisältyvät muihin sosiaalisiin prosesseihin. Näitä prosesseja ovat esimerkiksi rotu, luokka, seksuaalisuus, uskonto, ikä ja fyysiset ominaisuudet. (Acker 2006, 445.)

Sukupuolistuneet prosessit sitoutuvat laajempiin yhteiskunnallisiin ja globaaleihin vaikuttimiin, joista tärkein on yliopistojärjestelmän kokema rakenteellinen muutos. Esimerkiksi Suomessa yliopistojen toimintaympäristöjä ja organisaatiokulttuuria ryhdyttiin systemaattisesti uudistamaan 1990-luvulla ja muutostrendi näyttää entisestään kiihtyvän. Muutokset ovat koskettaneet koko yliopistolaitosta: sen perusluonnetta, velvollisuuksia, taloutta, rahoitusmalleja, kilpailukykyä sekä hallinto- ja johtamistapoja. Vuoden 2010 alussa voimaan tullut uusi yliopistolaki sinetöi yliopistouudistukseksi kutsutun prosessin, jonka seurauksena suomalaiset yliopistot muuttuivat valtion virastoista julkisoikeudellisiksi laitoksiksi tai säätiöiksi. (Jauhiainen 2011, 164; Koivula, Rinne \& Niukko 2009, 8.)

Yliopistouudistuksella on ollut vaikutuksia myös tutkimushenkilöstöön. Tämä näkyy esimerkiksi työajan pidentymisenä, toisarvoisten työtehtävien ja työmäärien lisääntymisenä, tulos- ja tehokkuusvaatimuksina, palkkauksen muutoksina, pätkätöiden ja määräaikaisten työsuhteiden kasvuna sekä kiristyvänä kilpailuna niin rahoituksen kuin aseman suhteen. (Hakala, Kaukonen, Niemi \& Ylijoki 2003, 10; Jauhiainen 2011, 164; Ylijoki \& Aittola 2005, 9.) Uuden yliopistojärjestelmän on katsottu olevan sukupuolineutraali ja parantavan sukupuolten tasa-arvoisuutta. Tosiasiassa tutkijanaisten asema on muuttunut vähän, jos lainkaan (Fletcher 2007, 271). Onkin kiinnostavaa tarkastella, kuinka yliopistokulttuurin muutos on entisestään vahvistanut yliopiston sukupuolistunutta organisaatiokulttuuria.

\section{NAISTEN JA MIESTEN TYÖT: SUKUPUOLISTUNUT TYÖNJAKO}

Tutkimaamme yliopistoa on kutsuttu yhdeksi Suomen naisistuneimmaksi yliopistoksi, sillä sen opiskelijoista sekä opetus- ja tutkimushenkilöstöstä enemmistö on naisia. Myös professorikunnasta naisten osuus on puolet. Vaikka sukupuolistuneet työnjaot eivät näy 
työtehtäviin sijoittumisessa, tuotetaan sukupuolieroja epävirallisen työnjaon kautta.

Ackerin $(1992,252)$ mukaan epävirallisen työnjaon avulla organisaatiossa määritellään naisten ja miesten työt sekä niiden väliset valtasuhteet ja arvostuserot. Tutkijanaiset pohtivat aineistomme vastauksissaan sukupuolistunutta työnjakoa:

"Naisille yritetään jatkuvasti sysätä kaikki käytännön järjestelyt, 'koska se hoituu heiltä niin luontevasti'."

"Tutkijanaisille kohdennetaan enemmän opetukseen liittyviä tehtäviä, kun taas miehille tarjotaan enemmän mahdollisuuksia oman tutkimuksen tekoon ja julkaisuun."

Aineistosta selvisi, että yliopistossa jaetaan työtehtäviä traditionaalisten sukupuoliroolien perusteella. Tutkijanaisille suunnattuja työtehtäviä olivat muun muassa erilaiset hallinto- ja toimistotehtävät sekä käytännön asioista huolehtiminen. Oppilaiden ohjaus, opetus ja siihen liittyvät järjestelyt kuuluivat osaksi tutkijanaisten työnkuvaa. Tutkijamiehet saivat puolestaan keskittyä tutkimukseen ja heille suunnattiin enemmän uralla etenemistä tukevia töitä, joita olivat erilaiset asiantuntija- ja johtotehtävät.

Vastaavissa tutkimuksissa (Naskali 2004; Van den Brink \& Benschop 2011) on todettu, että sukupuolistuneella työnjaolla on konkreettisia vaikutuksia tutkijanaisten asemaan ja urakehitykseen. Hallinto- ja toimistotehtävistä aiheutuvat suuret työmäärät ja aikatauluongelmat heikentävät huomattavasti tutkijanaisten mahdollisuuksia tutkimusten ja julkaisujen tekoon (Naskali 2004, 22). Opetukseen liittyvät tehtävät eivät pätevöitä tutkijanaisia, sillä opetukselliset taidot eivät ole verrattavissa tutkimukselliseen tuottavuuteen (Van den Brink \& Benschop 2011, 514). Toisaalta suurin osa sukupuolten palkka- ja työsuhteen laatuun liittyvistä eroista on seurausta sukupuolistuneesta työnjaosta (Kantola 2005, 206).

Aineistosta löytyi viitteitä siitä, että uuden yliopistojärjestelmän työmäärät ovat radikaalisti lisääntyneet. Yhä enemmän aikaa kuluu työn by- rokraattiseen suunnitteluun, raportointiin ja arviointiin. Moni tutkijanainen huomautti, että tällaiset yliopiston toisarvoiset työtehtävät sysätään yleensä naisten vastuulle.

"Hallinnollisten työtehtävien jaossa miespuolisten kollegojen kiireet tuntuvat olevan hyväksyttävämpiä kuin minun kiireeni, jolloin ne sysätään minulle hoidettavaksi."

Acker ja Armenti toteavat, että yliopistossa työskentelevät tutkijanaiset ovat kokeneet eniten paineita lisääntyneistä työmääristä ja tuloksellisuusvaatimuksista. Naiset näyttivät vastaavan tehokkuus- ja tuottavuusvaatimuksiin vapaa-aikansa ja yksityiselämänsä kustannuksella. (Acker \& Armenti 2004, 19-21.) Toisin sanoen yliopistokulttuurin muutoksella onkin ollut sukupuolen eriarvoisuutta lisääviä vaikutuksia. Vaarassa on, että tutkimustyö uhkaa eriytyä kokonaan miesten alueeksi.

Tutkimuksessamme kävi ilmi, että tutkijanaisten oletetaan suorittavan heille annetut työtehtävät tunnollisesti ja tavoiteaikataulussa. Heidän odotetaan huolehtivan sellaisistakin työtehtävistä, joita virallisessa vastuussa ollut henkilö ei ole saanut hoidetuksi. Tutkijamiehet eivät kohtaa samanlaista vastuullistamista ja heille annetaan enemmän vapauksia valikoida työtehtäviä. Eräs tutkijanainen kuvasi tilannetta seuraavasti:

"Ylimääräinen vastuullistaminen, itsestään selvänä pidetyt odotukset erilaisiin ryhmiin osallistumisesta tai back-upista silloinkin kun varsinainen virallisessa vastuussa oleva henkilö ei ole hoitanut asiaa oletetaan, että nainen loppupeleissä ottaa kopin. Tämä vaikeuttaa selkeästi oman työn hallintaa."

Naskali on todennut, että naisten velvollisuutta ja vastuullisuutta on helppo käyttää hyväksi velvoitettaessa heitä tekemään töitä, jotka on pakko hoitaa yliopiston toiminnan ylläpitämiseksi. Kun useat tutkijanaiset ovat lisäksi määräaikaisissa työsuhteissa, ei heillä ole rohkeutta puolustaa oikeuttaan työnkuvansa määrittelyyn. (Naskali 2004, 20.) Tutkijanaiset muodostavat resurssin, jota voidaan käyttää tulostavoitteiden saamiseen, ja joka voidaan tarvittaessa nopeasti siirtää sivuun (Brunila 2009, 50). 
HYMYILEVIÄ SIHTEEREITÄ, AHKERIA ÄITEJÄ JA TIEDEMIEHIÄ: SUKUPUOLISTUNEET MIELIKUVAT

Julkisuudessa yliopistoon liitetään usein mielikuvia tasa-arvoisuudesta ja yhteisöllisyydestä. Aineistoista piirtyi kuitenkin esille useita sukupuolistuneita mielikuvia, joita yliopiston sisäisessä organisaatiokulttuurissa esiintyy. Ackerin $(1992,253)$ mukaan sukupuolistuneiden mielikuvien tarkoituksena on ylläpitää hegemonista maskuliinisuutta ja uusintaa sukupuolijakoa.

Ensimmäinen sukupuolistunut mielikuva liittyy ideaaliseen tutkijakuvaan. Tutkijanaisten vastausten perusteella tutkijamiehet nähtiin ensisijaisesti tiedon tuottajina ja tieteellisinä asiantuntijoina. Sukupuolistuneiden mielikuvien vuoksi tutkijanaisten tieteellisiä kykyjä ja asiantuntijuutta usein aliarvioitiin tai vähäteltiin. Kärjistäen tutkijanaiset nähtiin mielikuvissa enemmän "hymytyttöinä", "ahkerina sihteerikköinä" ja "huolehtivina äitihahmoina" kuin potentiaalisina tutkijoina. Yksi tutkijanainen kuvasi kokemustaan näin:

"Tietyissä tapauksissa olen kokenut, etten tule arvostetuksi tutkijana vaan ensisijaisesti sihteerikkönä. Yksittäisenä esimerkkinä vaikkapa tilanne, jossa eräs professori konferenssin jälkeen kiittää miespuolista kollegaani puheenvuorojemme jälkeen kunnianhimoisesta ja inspiroivasta esitelmästä ja minua taas kauniista hymystä ja huolenpidosta."

Julkunen toteaa, että akateemisessa maailmassa sukupuolistuneet mielikuvat ovat hitaasti muuttuvia ja naisten kykyjä tieteelliseen ajatteluun on epäilty kautta aikojen. Esimerkiksi historiallisesti katsottuna mielikuva ideaalisesta tutkijasta on ollut hyvin miehinen. Tutkija tai tiedemies nähtiin rationaalisena, sivistyneenä intellektuellina, joka oli täysin tieteelle omistautunut. 2000-luvun yliopistokulttuurin muutoksen jälkeen tiedemiesideaali on vaihtunut individualistiseen, aggressiiviseen ja kilpailulliseen manageriprofessoriin, joka ei ole sen naisellisempi mielikuva. (Julkunen 2004, 197.) Toisin sanoen yliopistokulttuurin muutos on vahvistanut maskuliinista tiedemieskuvaa, jossa tutkijamiehillä on etuoikeus tieteellisen tiedon tuottamiseen.
Toinen aineistossa erottuva mielikuva liittyy maskuliinisia arvoja korostavaan tutkijanuramalliin, johon yliopistokulttuurin muutoksella on ollut merkittävä vaikutus. Tämän mielikuvan mukaan tutkijoiden uralla eteneminen vaatii pitkän työajan sietämistä, omistautumista työlle ja yksityiselämän marginalisoimista, kovaa kilpailua sekä useita tieteellisiä julkaisuja. Monelle tutkijanaiselle tällainen miehinen urakehitysmalli osoittautui mahdottomaksi toteuttaa muun muassa perhevelvollisuuksien sekä opetusja hallintotehtävien kasaantumisen vuoksi. Toisaalta moni vastanneista arvosti myös vapaa-aikaansa, jota he eivät halunneet uhrata työnteolle.

"En jaksa ainaista vähättelyä, että tämä nyt vain kuuluu tieteen tekemiseen, että tutkimusta tehdään omalla ajalla (tarkoittaa, että lepoon ja rauhaan ei ole aikaa)."

Useiden tutkimusten perusteella tällainen sukupuolistunut meritoitumismalli on tutkijanaisten kannalta epäedullinen. Tutkijanaisten ura etenee tutkijamiehiä hitaammin muun muassa raskauden, perhevelvoitteiden sekä opetus- ja hallintotehtävien kasaantumisen vuoksi. (Esim. Foster 2001; Harley, 2003; Knights \& Richards 2003; Van den Brink \& Benschop 2012.)

Kolmas aineistosta esiin nostettu sukupuolistunut mielikuva liittyy perheellisyyteen ja äitiyteen. Naiset nähtiin ensisijaisesti sukupuolensa edustajina, joilla oli lapsia tai jotka hankkivat tulevaisuudessa lapsia. Sukupuolistuneiden mielikuvien johdosta tutkijanaiset nähdään eräänlaisina rakenneriskeinä, mikä voi hankaloittaa avoimiin työtehtäviin pääsyä tai määräaikaisten työsuhteiden uusimista. Myös Perna (2005, 300-302) toi tutkimuksessaan esille, että perheellisyys ja lasten saaminen heikensi tutkijanaisten mahdollisuuksia saada pysyvä työsuhde tai korkeampi virka akateemisessa maailmassa. Eräs tutkijanaisista kommentoi aihetta:

"Perheen perustaminen hieman huolettaa, sillä vaikka en usko esim. äitiyslomalle jäämisen suoraan vaikuttavan asemaani niin vähintäänkin tulisin jäämään jälkeen tuotettujen julkaisujen määrässä. Ja juuri näillä kuitenkin ratkaistaan kilpailu seuraavista työsuhteista." 
Yliopiston organisaatiokulttuurissa esiintyvät perheellisyyteen ja äitiyteen liittyvät stereotyyppiset näkemykset leimaavat kaikkia tutkijanaisia, niitäkin, joiden tulevaisuuteen ei kuulu perheen perustaminen. Naskalin $(2004,28)$ mukaan nainen määrittyy akateemisessa maailmassa edelleen muiden kautta: jonkun vaimona, äitinä tai huoltajana eikä itsenäisenä työntekijänä, jonka perhe-elämä ei vaikuta työntekoon.

\section{VELJET, SISKOT JA ULKOPUOLISET:}

\section{SUKUPUOLISTUNUT VUOROVAIKUTUSKULTTUURI}

Ackerin $(1990,146)$ mukaan miesten ja naisten, työntekijöiden ja johtajien sekä kollegoiden välisessä vuorovaikutuksessa on näkyvissä erilaisia sukupuolistuneita käytänteitä, jotka tuottavat ja uusintavat miesten valta-asemaa hierarkian eri tasoilla. Husu ja Kantola ovat tutkimuksissaan todenneet, että yliopistojen vuorovaikutusjärjestelmä perustuu miehiselle toimintakulttuurille ja miehisen sisäpiirin harjoittamalle vallankäytölle (Husu 2001, 160; Kantola 2005, 12).

Tutkimusaineiston pohjalta voi todeta, että tutkimamme yliopiston vuorovaikutuskulttuuri oli monin tavoin sukupuolistunutta. Huolimatta henkilökunnan naisenemmistöstä, yliopiston naisrintama sekä yhteisöllisyys rakoilivat. Tutkijanaiset puhuivat erilaisista miesten muodostamista verkostoista. Toisaalta vastauksista selvisi, että organisaation sisällä oli myös erilaisia naisten muodostamia ryhmittymiä. Kiinnostavaa on, että nämä naistenkin muodostamat verkostot näyttävät omaksuneen miehiset toimintatavat ja vallankäyttömuodot. Kun Bagilhole \& Goode (2001) puhuvat tutkimuksessaan akateemisen maailman patriarkaalisista tukisysteemeistä tai hyvä veli -verkostoista, voidaan tutkimassamme yliopistossa todeta esiintyvän matriarkaalisia tukisysteemejä, eräänlaisia hyvä sisko -verkostoja.

Pysyäkseen valta-asemassa verkostot käyttivät erilaisia vallankäytön muotoja. Yksi merkittävimmistä valtatekniikoista oli tutkijanaisten ulossulkeminen tiedeyhteisöstä. Moni tutkijanainen kuvasi suhdettaan työyhteisöön etäiseksi ja ulkopuoliseksi. Ulkopuolisuus ja kokemus näkymättömyydestä leimasivat erityisesti aloittelevien tai juuri työyhteisöön tullei- den tutkijanaisten arkea. Toisaalta osa tutkijanaisista kertoi tuntevansa olleensa tiedeyhteisönsä ulkopuolella useiden vuosien ajan. Muita aineistossa esiintyneitä ulossulkemisen muotoja olivat sosiaalisen tuen, ohjauksen ja kannustuksen puute, kuulluksi tulemisen vaikeus, tervehtimättä jättäminen, työhuoneen saantiin liittyvät epäselvyydet sekä tiedonkulkuun liittyvät vaikeudet. Tutkijanaiset kuvasivat kokemuksiaan ulkopuolisuudestaan seuraavasti:

"Henkinen koti ei ole siellä, missä hallinnollinen 'kotipaikka' on. Jatkuvuuden tuntua ... yliopistossa ei ole."

"Olen pettynyt siihen, miten huonosti työyhteisön sisään pääseminen on hoidettu... Perehdytystä ei ollut alussa lainkaan, eikä minulle esitelty ketään tai minua kenellekään. Tilannetta ei helpota yhtään se, että istun muista erillään. Joten työyhteisön näkökulmasta olen kokenut olevani hyvin yksin."

"Syrjintä on epäsuoraa: huomiotta jättämistä ja kuulluksi tulemisen vaikeutta."

"Miesverkosto jakaa tietoa keskenään ja sulkee infon ulkopuolelle muita kollegoita."

Foster ja Nikunen ovat tutkimuksissaan pohtineet syitä tutkijanaisten vaikeuksiin integroitua tiedeyhteisöönsä ja sisäpiiriverkostoihin. Ratkaisuksi on tarjottu naisroolimallien ja mentoreiden lisäämistä sekä naiskiintiöiden vakiinnuttamista hierarkian ylemmillä tasoilla. (Foster 2001, 29; Nikunen 2006, 26.) Tutkimustulostemme pohjalta ei voida päätyä vastaavaan ratkaisumalliin, koska kohdeyliopistossa ylemmille hierarkiatasolle edenneiden tutkijanaisten osuus on jo varsin korkea. Naisten marginalisointi on siten tehokas vallankäytön muoto myös naisten keskinäisissä suhteissa.

Toinen aineistosta esiin nostettu vallankäytön muoto liittyi tutkijanaisten tieteellisen asiantuntemuksen tai tutkimustyön aliarvioimiseen ja vähättelyyn. Tutkijanaiset kuvasivat kokemuksiaan seuraavasti:

"Miehiä kannustetaan yleisesti tutkijoina enemmän. Heidän tutkimuksensa koetaan arvokkaammiksi ja tieteellisesti painavammiksi." 
"Ei ole poikkeus täälläkään, että naisilta vaaditaan kaksinkertainen työpanos, jotta hänen työtään oikeasti arvostettaisiin."

Tutkijanaisten vastausten perusteella miehiä arvostetaan tutkijoina enemmän. Tutkijamiesten harjoittama tutkimustyö aiheineen ja menetelmineen nähdään tieteellisesti merkittävämmäksi kuin naisten tekemä tutkimustyö. Tutkijanaiset kokivat joutuvansa ponnistelemaan runsaasti saadakseen kiitoksen työstään.

Tieteellisissä arvioinneissa saattaa esiintyä huomattavia sukupuolivinoumia. Esimerkiksi Bencshopin ja Brounsin tutkimuksessa todettiin, että vaikka naiset ovat objektiivisten kriteerien perusteella yhtä päteviä tutkijoita kuin miehet, määritellään mieshakijat usein "erinomaisiksi tutkijalupauksiksi", kun taas naishakijat ovat korkeintaan "hyviä tutkijalupauksia”. Lisäksi mieshakijat eivät olleet niin hyviä kuin arvostelut ja lausunnot antoivat ymmärtää ja vastaavasti naiset olivat parempia kuin mitä arvioissa annettiin ymmärtää. (Benschop \& Brouns 2003, 205.) Wenneråsin \& Woldin (1997, 1-5) tutkimuksessa huomattiin, että tieteellisen työn arvioiminen ei ole sukupuolineutraalia, sillä naisten on oltava kaksi kertaa tuottavampia kuin miehet, jotta he saavuttaisivat erinomaisuuden määreen.

Aineistossa kiinnitimme huomiota myös siihen, että yliopistokulttuurin muutos on lisännyt vastakkainasettelua ja kiristänyt kilpailua tutkijoiden välillä. Tämä heijastuu työyhteisön vuorovaikutukseen, jota eräs tutkijanainen kuvaa:

"Kilpailua ja tuuppimista tapahtuu niin naisten kuin miesten taholta vähäisiä toimia haettaessa. Mitä pidemmälle kouluttautuu, sitä kovempaa kilpailu on apurahoista, toimista ja titteleistä."

Tutkijanaisten tieteellisen asiantuntemuksen vähättely näkyi voimakkaimmillaan esimerkeissä, jotka ilmensivät muutamien tiedeyhteisössä toimivien kollegoiden aggressiivista ja julkiseen nolaamiseen tähtäävää toimintaa:

"Yliopiston opetushenkilökuntaan kuuluva miespuolinen henkilö arvosteli henkilökohtaisia ominaisuuksiani sekä tutkimusaihettani muiden kurssilaisten kuullen. Tapaus herätti epäuskoa sekä tunteen nöyryytetyksi tulemisesta ja epäoikeudenmukaisesta kohtelusta."

Vastaavissa tutkimuksissa on todettu, että miesten harjoittama vastustus ja piittaamattomuus tutkijanaisia kohtaan on yksi tärkeimmistä keinoista, joilla miehistä toimintakulttuuria ja maskuliinista hegemoniaa ylläpidetään (O'Connor 2000, 218). Kuitenkaan tiedeyhteisöjen sukupuolistunut vuorovaikutuskulttuuri ei aina johdu miesten toimintatavoista. Tutkimusaineistosta löytyi useita esimerkkejä naisten harjoittamasta syrjivästä ja epäoikeudenmukaisesta käyttäytymisestä.

"Minusta on tärkeää tässä yhteydessä mainita, että ... ei ole kyse siitä, että miehet syrjivät naisia, vaan näin naisvaltaisessa yliopistossa naisia syrjivät useimmiten toiset naiset."

"Itse olen naispuolisten esimiesten taholta kokenut pahempaa suoraa ja epäsuoraa syrjintää kuin miespuolisen esimiehen."

Naskali $(2007,184)$ huomauttaa, että naisenemmistö ei aina muodosta yhteistä rintamaa, sillä naiset kilpailevat paljolti keskenään ja asettuvat hierarkiassa sen alimmille portaille, toimistotyöhön ja määräaikaisiksi tutkijoiksi ja assistenteiksi. Naisistuminen sinänsä ei siten ole ratkaisu sukupuolisen syrjinnän ehkäisylle.

\section{NÄKYMÄTÖN VAI RIITASOINTU? SUKUPUOLISTUNUT ITSEMÄÄRITTELY}

Ackerin mukaan yksilö pyrkii muodostamaan käsityksen organisaation toimintakulttuurista ja arvioimaan asemansa sukupuolen edustajana organisaatiossa. Tämä tapahtuu yleensä omaksumalla omalle sukupuolelle sopiva käyttäytyminen ja asenteet. (Acker 1992, 254; Acker 1990, 146.) Yliopiston sukupuolistunut organisaatiokulttuuri tarjosi tutkijanaisille erilaisia mahdollisuuksia määritellä omaa asemaansa ja asiantuntijaidentiteettiään. Tutkimusaineiston pohjalta käyttäytyminen ja asenteet voidaan karkeasti jakaa neljään strategiaan: (1) mukautujat, (2) ulkopuoliset, (3) valtaa käyttävät sekä (4) uudistusmieliset. 
Selvästi yleisin strategia hahmottaa toimijuuttaan oli mukautuminen organisaation tarjoamiin traditionaalisiin sukupuolirooleihin. Tutkijanaiset olivat töiden suhteen ahkeria ja vastuullisia eivätkä kieltäytyneet ylimääräisistä työnkuvista. He olivat kilttejä ja huolehtivat opiskelijoiden sekä muiden työntekijöiden tarpeista. Nämä tutkijanaiset katsoivat, että noudattamalla omalle sukupuolelle sopivaa käyttäytymistä, heidän on mahdollista saada näkyvyyttä työlleen sekä lunastaa asemansa tiedeyhteisössä. Eräs tutkijanaisista totesi:

"Otan vastaan minulle tarjotut roolit ja tehtävät ja jopa tarjoudun niihin itse. Koen, että asiat eivät hoidu, jos minä en niitä tee. Toisaalta tiedostan, että tilanne on omasta ajatusmaailmastani ja asenteistani kiinni."

Horellin ja Saaren mukaan sukupuoliroolit uusintavat perinteisiä naisten ja miesten rooleja ja määrittävät rajoja soveliaalle ja sopimattomalle. Jähmettyneet sukupuoliroolit kaventavat inhimillisen potentiaalin täyttä hyödyntämistä ja asettavat kummallekin sukupuolelle tiukat epätasa-arvoa edistävät rajat. (Horelli \& Saari 2002, 52-53.) Toisaalta perinteisiä sukupuolirooleja noudattamalla vahvistetaan yliopiston organisaationkulttuurin hegemonista maskuliinisuutta.

Toiseksi yleisin tutkijanaisten käyttämä strategia oli määritellä itsensä ulkopuoliseksi. Tämän strategian omaksuneet tutkijanaiset kokivat usein vierautta maskuliinisia arvoja korostavassa organisaatiokulttuurissa. Tutkijanaiset kokivat itsensä yksinäisiksi ja näkymättömiksi tiedeyhteisössään. He suhtautuivat omaan asiantuntijuuteensa kriittisesti ja vähätellen. Eräs tutkijanaisista kuvasi tilannettaan:

"Olen vain monta vuotta ollut 'joku, vissiin tutkija', jonka olemassa olo ei ole yliopiston 'oikeiden' tehtävien kannalta ole merkityksellistä. Tämä on aiheuttanut sen, etten ole kulkenut laitoskokouksissa tai muissa yhteisissä jutuissa. Kukaan ei tiedä, mitä teen, eikä ole siitä oikein kiinnostunutkaan."

Husu $(2004,9)$ on huomauttanut, että osa tutkijanaisista voi suhtautua kriittisesti maskuliiniseen toimintakulttuuriin ja valita vetäytymisen strategian, jolloin marginaalisuus ja ulkopuolisuus ymmärretään tutkijan omaksi valinnaksi. On tärkeää ymmärtää, että tämä marginaalisuus on piilevien rakenteiden tuotos. Se on osa sukupuolistuneen organisaation toimintaa, joka kasvattaa sukupuolenmukaista syrjintää. (Kantola 2005, 86.)

Vallan käyttämisen strategia oli myös melko yleinen tapa rakentaa omaa asiantuntijuutta. Tämän strategian omaksuneet tutkijanaiset hyväksyivät maskuliinisuuden normina ja korostivat sitä, ettei sukupuolella ollut merkitystä. Heidän mielestään ainoastaan yksilön henkilökohtaiset kyvyt ratkaisevat sen, millaiseksi asema organisaatiossa muodostuu. Tutkijanaiset pyrkivät tulemaan organisaatiossa miesten veroisiksi häivyttämällä tai luopumalla "feministisistä piirteistä”.

"Koen, että sukupuoli ei vaikuta asemaani tutkijana niin yliopistolla kuin kenttätyössäkään. Ainoastaan tieteellisen tutkimuksen taso ja itseilmaisukyky määrittelevät sen, miten etenen urallani."

Katila ja Meriläinen (2002, 339) ovat huomauttaneet, että tällaisella käyttäytymismuodolla tutkijanaiset joko tiedostamatta tai tietoisesti ylläpitävät tiedeyhteisöjen maskuliinista hegemoniaa. Toisaalta toimintatapa voi aiheuttaa ristiriitoja ja hierarkkisia vastakkainasetteluja tutkijanaisten keskinäisiin suhteisiin.

Neljäs strategia käsittää uudistusmieliset tutkijanaiset. Uudistusmielisyys oli selvästi vähiten käytetty tapa, jolla tutkijanaiset rakensivat omaa asiantuntijuuttaan. Tämän strategian sisäistäneet tutkijanaiset eivät hyväksy miesten ylivaltaa, vaan pyrkivät aktiivisesti vastustamaan ja haastamaan vallitsevaa maskuliinista toimintakulttuuria. Tutkijanaiset ovat tietoisia organisaatiossa esiintyvistä ongelmista, jotka asettavat heidät eriarvoiseen asemaan. He pyrkivät omalla toiminnallaan saamaan aikaan muutosta ja tuomaan esille organisaatiokulttuurissa esiintyviä epäkohtia.

"Nykyisin tasa-arvoasioihin kiinnitetään enemmän huomiota, mutta kuitenkin esimerkiksi uuden yliopistolain jälkeen naisten ja miesten palkkaerot ovat kasvaneet. Oikeasti on tehtävä jotain!"

"Tärkeää olisi puhua avoimesti naisten ja miesten välisestä epätasa-arvosta yhteiskunnan tasolla ja samalla tunnustaa, että yliopistossakin on samanlaisia ongelmia kuin muualla yhteiskunnassa." 
KUVA YLIOPISTOSTA

TASA-ARVOISENA, YHTEISÖLLISENÄ

JA PERHEM $\ddot{I S E N ~} \ddot{A}$

ORGANISAATIONA

SÄRÖILI JA OSOITTAUTUI

TARKEMMIN TARKASTELTUNA

ILLUUSIOKSI.

Kuten lainausten pohjalta voi havaita, tutkijanaisista on tullut aktiivisia ja näkyviä toimijoita. Aikaisemmissa tutkimuksissa on todettu, että tällainen käyttäytymismuoto voi olla riski, sillä tiedeyhteisöt ovat hyvin vastustuskykyisiä muutoksille, ja aktiivisesti tiedeyhteisön maskuliinisuutta purkavat tutkijanaiset voivat joutua kohtaamaan laajaa vastustusta (Kantola 2008, 218; Katila \& Meriläinen 1999, 171).

\section{JOHTOPÄÄTÖKSET}

Tutkimusaineiston perusteella kuva yliopistosta tasa-arvoisena, yhteisöllisenä ja perhemäisenä organisaationa säröili ja osoittautui tarkemmin tarkasteltuna illuusioksi. Analyysin pohjalta selvisi, että tutkimassamme yliopistossa tutkijanaiset olivat kohdanneet useita sukupuolisen syrjinnän muotoja, jotka heikensivät heidän asemaansa niin työntekijöinä kuin tieteellisinä asiantuntijoina. Tärkein syy siihen, miksi sukupuolten tasa-arvo-ongelmia esiintyy edelleen akateemisessa maailmassa, näyttäisi olevan yliopisto-organisaatioiden hahmottaminen sukupuolineutraaleina. Ajatus organisaatioiden sukupuolineutraaliudesta on johtanut siihen, ettei organisaatiossa esiintyviä sukupuolistavia käytäntöjä tunnisteta helposti tai niihin suhtaudutaan itsestäänselvyyksinä.
Sukupuolineutraaliuden idean pohjalta on myös vahvistettu erilaisia selityksiä tasa-arvosta. Esimerkiksi tutkimamme yliopisto on kuvattu naisistuneeksi, koska se on opiskelija- ja henkilöstömääriltään naisenemmistöinen. Tämänkaltainen asetelma on saanut monet julistamaan tutkijanaisten tasa-arvon saavutetuksi. On kuitenkin tärkeää tiedostaa, että huolimatta syrjinnän kieltävistä laeista, tasa-arvosuunnitelmista tai yliopiston opiskelija- ja henkilökunnan naisistumisesta, sukupuolten tasaarvo-ongelmat eivät katoa itsestään. Syyt tutkijanaisten aseman eriarvoisuuteen ja sukupuolten epätasaarvoon löytyvät yliopistojen sukupuolistuneesta organisaatiokulttuurista.

Tutkimusaineiston perusteella tutkimaamme yliopistoa voidaan kuvata sukupuolistuneena organisaationa, jossa esiintyvät Ackerin (2006, 1992,1990) teorian neljä sukupuolistunutta prosessia. Huomioitavaa on, että nämä sukupuolistuneet prosessit esiintyivät usein piilossa olevina, luonnollisina ja hitaasti muuttuvina käytäntöinä, joita on vaikea tunnistaa ja muuttaa. Tutkimustulosten mukaan sekä miehet että naiset tuottivat ja ylläpitivät sukupuolistuneita prosesseja työssään omien ajattelu- ja toimintatapojensa kautta.

Ensinnäkin yliopistossa tuotetaan sukupuolieroa epävirallisen työnjaon kautta. Tutkimustulosten pohjalta tutkimustyö sekä erilaiset asiantuntija- ja johtotehtävät on luonnollistettu miesten alueeksi. Tutkijanaisille suunnattuja työnkuvia ovat opetustehtävät, erilaiset hallinto- ja toimistotyöt sekä käytännönjärjestelyistä huolehtiminen. Tämänkaltaiset työtehtävät hidastavat tutkijanaisten urakehitystä, sillä ne vievät aikaa tutkimustyöltä eikä niistä kerry tutkimuksellista meriittiä.

Toiseksi yliopiston organisaatiokulttuurissa ylläpidetään sukupuolistuneita mielikuvia ja stereotyyppisia käsityksiä, jotka tulevat esille tiedemiesajattelussa, miehisessä urakehitysmallissa sekä perheellisyyteen liittyvissä kysymyksissä. Näiden sukupuolistuneiden ajattelutapojen johdosta tutkijanaisiin kohdistetaan usein epäilyjä heidän kyvyistään ja mahdollisuuksistaan tehdä tutkimustyötä.

Kolmanneksi yliopiston vuorovaikutuskulttuuri on monin tavoin sukupuolistunutta ja se perustuu 
paitsi miesten myös naisten muodostamien ryhmien vallankäytölle. Säilyttääkseen valta-asemansa nämä ryhmittyvät käyttävät erilaisia vallankäytön tekniikoita. Näitä olivat tutkijanaisten ulossulkeminen tiedeyhteisöstä sekä heidän tieteellisten kykyjensä ja asiantuntemuksensa vähättely.

Neljänneksi yliopisto tarjosi tutkijanaisille erilaisia sukupuolistuneita tapoja rakentaa omaa tieteellistä asiantuntijuuttaan ja määritellä omaa asemaansa. Tulosten mukaan ne voidaan jakaa neljään strategiaan, jotka olivat mukautujat, ulkopuoliset, valtaa käyttävät sekä uudistusmieliset. Merkille pantavaa on, että enemmistö tutkijanaisista mukautui organisaatiokulttuurin heille tarjoamiin traditionaalisiin sukupuolirooleihin. He olivat ahkeria, kilttejä, osin huomaamattomia ja ennen kaikkea velvollisuudentuntoisia.

Nämä neljä sukupuolistunutta prosessia eivät ole irrallisia, vaan osa laajoja yhteiskunnallisia ja globaaleja muutoksia. Yliopistojen toimintaympäristö ja organisaatiokulttuuri ovat kohdanneet ja kohtaavat edelleen laajoja muutoksia. Yliopiston on täytynyt sopeutua niin resurssileikkauksiin, uuteen johtamisjärjestelmään, tulos- ja tehokkuusvaatimuksiin, opetuksen ja tutkimuksen laadun arviointiin, kiristyvään kilpailuun kuin henkilöstön aseman muutokseen. Tutkimuksemme mukaan muutokset ovat entisestään vahvistaneet sukupuolistunutta organisaatiokulttuuria ja heikentäneet tutkijanaisten asemaa.

Yliopistokulttuurin muutokset heijastuvat ensisijaisesti tutkijanaisten työhön. Tutkijanaisten työnkuva on muuttunut aikaisempaa ristiriitaisemmaksi, sillä jo ennestään suuret työmäärät ovat lisääntyneet ja työajat pidentyneet. Aihe on erityisen ajankohtainen nyt, koska hallitus kohdistaa yliopistojen rahoitukseen mittavia leikkauksia. Ne asettavat yliopistot entistä ahtaammalle ja henkilöstömäärän vähentämiseltä tuskin vältytään. Kuormittavatko esimerkiksi projekteihin liittyvät hallintotehtävät lisääntyvässä märin juuri tutkijanaisia? Eriytyykö tieteellinen tutkimustyö entistä enemmän tutkijamiesten alueeksi? Rahoituksen vähentäminen kiristää entisestään kilpailua sekä tutkijoiden että yliopistojen välillä.

Yliopistokulttuurin uudistuksen myötä markkinat märïttelevät yhä enemmän sitä mikä on tutkimisen arvoista. Markkinavetoisuuden myötä tieteen kilpajuoksussa menestyvät yhä enemmän tekniikan- ja luonnontieteen alat, jolloin naisvaltaisten alojen on yhä vaikeampaa saada rahoitusta ja arvostusta. Uhkana on tieteellisen tutkimustyön ja sen intressien rapautuminen.

Tulevaisuudessa onkin tärkeää asettaa kysymys organisaatioiden sukupuolineutraaliudesta kriittisen tarkastelun kohteeksi. Yliopisto-organisaatiot on nähtävä kauttaaltaan sukupuolistuneina. Ne tuottavat ja ylläpitävät sukupuolten epätasa-arvoisuutta ja heikentävät tutkijanaisten asemaa. Tämän asian tunnistaminen ja tunnustaminen olisi merkittävä askel kohti nykyistä tasa-arvoisempaa, inhimillisempää yliopistomaailmaa. Huomioitavaa on myös se, että tulevaisuudessa suomalainen tutkimuskenttä tarvitsee kipeästi uutta tutkimustietoa yliopistokulttuurin sukupuolivaikutuksista.

Terhi Pietilä

KM, asiantuntija

Osaamisen kehittämispalvelut

Lapin työ- ja elinkeinotoimisto, Rovaniemi

Sari Poikela

$K T$, dosentti

Kasvatustieteiden tiedekunta

Lapin yliopisto 
Acker, J. (1990). Hierarchies, Jobs, Bodies: A Theory of Gendered Organizations. Gender \& Society 4(2), 139-158.

Acker, J. (1992). Gendering Organizational Theory. Teoksessa Mills, A.J. \& Tancred, P. (toim.) Gendering Organizational Analysis. Newbury Park, London \& New Delhi: Sage, 248-260.

Acker, S. \& Armenti, C. (2004). Sleepless in academia. Gender and Education 16(1), 3-24.

Acker, J. (2006). Inequality regimes. Gender, Class, and Race in Organizations. Gender \& Society 20(4), 441-464.

Andersson, G. (2006). Carving out time and space in the managerial university. Journal of Organizational Change Management 19(5), 578-592.

Bagilhole, B. \& Goode, J. (2001). The Contradiction of the Myth of Individual Merit and the Reality of a Patriarchal Support System in Academic Careers. A feminist Investigation. The European Journal of Women's Studies 8(2), 161-180.

Barone, C. (2011). Some Things Never Change: Gender Segregation in Higher Education Across Eight Nations and Three Decades. Sosiology of Education 84(2), 157-176.

Benschop, Y. \& Brouns, M. (2003). Crumbling Ivory Towers: Academic Organizing and Its Gender Effects. Gender, Work and Organization 10(2), 194-212.

Blickenstaff, J. (2005). Women and Science Careers: Leaky Pipeline or Gender Filter? Gender and Education 17(4), 369-386.

Brunila, K. (2009). Sukupuolten tasa-arvo korkeakoulutuksessa ja tutkimuksessa. Helsinki: Sosiaali- ja terveysministeriön selvityksiä 2009:51.

Bryson, C. (2004). The Consequences for Women in the Academic Profession of the Widespread Use of Fixed Term Contracts. Gender, Work \& Organization 11(2), 187-206.

Cohen, L., Manion, L. \& Morrison, K. (2000). Research methods on education. London: Routledge.

Crothers, L., Schmitt, A., Hughes, T., Lipinski, J., Theodore, L., Radliff, K. \& Ward, S. (2010). Gender Differences in Salary in a Female-Dominated Profession. Gender in Management: An International Journal 25(7), 605-626.

Currie, J., Harris, P. \& Thiele, B. (2000). Sacrifices in greedy universities: are they gendered? Gender and Education 12(3), 269-291.

Fletcher, C. (2007). Passing the buck: gender and management of research production in UK higher education. Management perspectives from a case study. Equal Opportunities International 26(4), 269-286.
Foster, N. (2001). A Case Study of Women Academics' Views on Equal Opportunities, Career Prospects and Work-Family Conflicts in a UK University. Career Development International 6(1), 28-38.

Hakala, J., Kaukonen, E., Nieminen, M. \& Ylijoki, O.-H. (2003). Yliopisto - tieteen kehdosta projektimyllyksi? Yliopistollisen tutkimuksen muutos 1990-luvulla. Helsinki: Gaudeamus.

Harley, S. (2003). Research selectivity and female academics in UK universities: From gentleman's club and barrack yard to smart macho? Gender and Education 15(4), 377-392.

Horelli, L. \& Saari, M. (2002). Tasa-arvoa valtavirtaan. Tasa-arvon valtavirtaistamisen menetelmiä ja käytäntöjä. Helsinki: Sosiaali- ja terveysministeriön selvityksiä. 2002:11

Huhta, L., Kolehmainen, S., Lavikka, R., Leinonen, M., Rissanen, T., Uosukainen, K. \& Ylöstalo, H. (2005). Tasa-arvosta lisäarvoa. Käsikirja työpaikkojen tasaarvotyöhön. Tampere: Vastapaino.

Husu, L. (2001). Sexism, support and survival in academia. Academic women and hidden discrimination in Finland. Helsinki: University of Helsinki, Department of Social Psychology.

Husu, L. (2004). Naisystävällisempään yliopistoon? Tiedenaiset ja muutoksen visiot. Naistutkimus Kvinnoforskning 1, 4-19.

Jauhiainen, A. (2011). Opetustyö ja sukupuoli uusliberalistisessa yliopistossa. Aikuiskasvatus 3/2011, 164-173.

Julkunen, R. (2004). Hullua rakkautta ja sopimustohtoreita. Jyväskylä: Jyväskylän yliopisto.

Kantola, J. (2005). Mykät, kuurot ja kadotetut. Sukupuolten välinen tasa-arvo Helsingin yliopiston valtio-opin laitoksella. Helsinki: Helsingin yliopisto.

Kantola, J. (2008). "Why Do All the Women Dissapear?" Gendering Processes in a Political Science Department. Gender, Work and Organization 15(2), 202-225.

Katila, S. \& Meriläinen, S. (1999). A Serious Researcher or Just Another Nice Girl?: Doing Gender in a MaleDominated Scientific Community. Gender, Work and Organization 6(3), 163-173.

Katila, S. \& Meriläinen, S. (2002). Metamorphosis: From "Nice Girls" to "Nice Bitches": Resisting Patriarchal Atriculations of Professional Identity. Gender, Work and Organization 9(3), 336-354.

Knights, D. \& Richards, W. (2003). Sex Discrimination in UK Academia. Gender, Work and Organization 10(2), 213-238. 
Koivula, J., Rinne, R. \& Niukko, S. (2009). Yliopistot yrityksinä? Merkkejä ja merkityksiä Suomessa ja Euroopassa. Kasvatus 2009(1), 7-27.

KOTA-Tietokanta (2014). Sukupuolijakaumat korkeakoulutuksessa. https://kotaplus.csc.fi

Kuula, A. (2006). Tutkimusetiikka. Aineistojen hankinta, käyttö ja säilytys. Tampere: Vastapaino.

Lavikka, R. (2004). Sukupuolineutraalius ja sukupuolistavat käytännöt tasa-arvon kehittämishankkeen näkökulmasta. Teoksessa Erikson, P., Hearn, J., Jyrkinen, M., Meriläinen, S., Moisander, J., Niemi, H., Rolin, K., Vanhala, S., Henttonen, E., Hiillos, M., Katila, S. \& Tallberg, T. (toim.) Sukupuoli ja organisaatiot liikkeessä? Helsinki: Swedish school of Economics and Bussiness Administration, 42-54.

Mäkinen, O. (2006). Tutkimusetiikan abc. Helsinki: Tammi.

Naskali, P. (2004). "Eihän meillä ole mitään ongelmia": Henkilökunnan ja opiskelijoiden kokemuksia tasaarvon ja yhdenmukaisuuden toteutumisesta Lapin yliopistossa. Rovaniemi: Lapin yliopisto.

Naskali, P. (2007). Kuin yhtä perhettä? Feministisiä näkökulmia Lapin yliopiston akateemiseen yhteisöllisyyteen. Teoksessa Autti, M., KeskitaloFoley, S., Naskali, P. \& Sinevaara-Niskanen, H. (toim.) Kuulumisia. Feministisiä tulkintoja naisten toimijuuksista. Rovaniemi: Lapin yliopistokustannus, 175-209.

Nikunen, M. (2006). "Ei mikään katastrofi kuitenkaan": selvitys sukupuolten välisestä tasa-arvosta Tampereen yliopisto tiedotusopin laitoksella. Tampere: Tampereen yliopisto.

O'Connor, P. (2000). Resistance Amongst Faculty Women in Academe. Higher Education in Europe 25(2), 213-219.
Perna, L. (2005). Sex differences in faculty tenure and promotion: The contribution of family ties. Research in Higher Education 46(3), 277-307.

Pietilä, T. (2014). Naisistumisen illuusio. Tutkijanaisten asema Lapin yliopistossa. Rovaniemi: Lapin yliopisto.

Raivio, K. (2002). Muuttuuko yliopisto tyttökouluksi? Pääkirjoitus. Yliopistolehti 16.

Seierstad, Cathrine \& Healy, Geraldine (2012). Women's Equality in the Scandinavian Academy: a Distant Dream? Work, employment and society 26:2, 296-313.

Tuomi, J \& Sarajärvi, A. (2009). Laadullinen tutkimus ja sisällön analyysi. Helsinki: Tammi.

Van den Brink, M., Brouns, M. \& Waslander, S. (2006). Does excellence have a gender? A national research study on recruiment and selection procedures for professorial appointments in The Netherlands. Employee Relations 28(3), 523-539.

Van den Brink, M. \& Benschop, Y. (2011). Gender Practices in the Construction of Academic Excellence: Sheep with Five Legs. Organization 19(4), 507-524.

Van den Brink, M. \& Benschop, Y. (2012). Slaying the Seven-Headed Dragon: The Quest for Gender Change in Academia. Gender, Work and Organization 19(1), 71-92.

VIPUNEN-tietokanta (2014). Sukupuolijakaumat korkeakoulutuksessa. http://vipunen.csc.fi (haettu 1.6 2014).

Wennerås, C. \& Wold, A. (1997). Nepotism and sexism in peer-review. Nature 22(387), 341-343.

Ylijoki, O. - H. \& Aittola, H. (2005). Johdanto: hyvää akateemista työtä etsimässä. Teoksessa Aittola, H. \& Ylijoki, O.-H. (toim.) Tulosohjattua autonomiaa. Akateemisen työn muuttuvat käytännöt. Helsinki: Gaudeamus, 7-17. 